\title{
Article \\ Hoeing as a Possibility for Mechanical Weed Control in Winter Oilseed Rape (Brassica napus L.)
}

\author{
Sebastian Schwabe*(D), Sabine Gruber and Wilhelm Claupein
}

Citation: Schwabe, S.; Gruber, S.; Claupein, W. Hoeing as a Possibility for Mechanical Weed Control in Winter Oilseed Rape (Brassica napus L.). Crops 2022, 2, 1-13. https://doi.org/ $10.3390 /$ crops 2010001

Received: 23 November 2021 Accepted: 21 December 2021 Published: 2 January 2022

Publisher's Note: MDPI stays neutral with regard to jurisdictional claims in published maps and institutional affiliations.

Copyright: (C) 2022 by the authors. Licensee MDPI, Basel, Switzerland. This article is an open access article distributed under the terms and conditions of the Creative Commons Attribution (CC BY) license (https:// creativecommons.org/licenses/by/ $4.0 /)$.
Institute of Crop Science (340a), University of Hohenheim, 70599 Stuttgart, Germany; sabine.gruber@uni-hohenheim.de (S.G.); claupein@uni-hohenheim.de (W.C.)

* Correspondence: sebastian.schwabe@uni-hohenheim.de

Abstract: The framework conditions for chemical weed control in oilseed rape (OSR) are becoming increasingly unfavorable in Central Europe. On the one hand, weed resistance is spreading and, on the other, there is a growing social desire to reduce or eliminate the use of chemical crop protection products. In a field experiment, hoeing, as a weed control measure performed two times per growing season (one time in autumn and one time in spring) in oilseed rape (Brassica napus; two varieties), was compared to chemical control by herbicides and a combination of hoeing and herbicide application (five treatments altogether). The chemical control by herbicides consisted of a broad-spectrum preemergence treatment and a post-emergence graminicide application. The trial was set up in each of three periods (years 2014/2015, 2015/2016, and 2016/2017) at the experimental station Ihinger Hof, University of Hohenheim, Stuttgart, Germany. The effect of the treatments on weed plant density, weed biomass at the time of harvesting, and on OSR grain yield was investigated. Weed plant density was measured four times per trial year, each time before and after hoeing. In 2015/2016 after spring hoeing, and in 2016/2017 at all data collection times, weed plant density was significantly higher in hoeing without herbicide application than in the other variants. No significant differences occurred at the other data collection times. The weed plant density ranged from 0.5 to 57.8 plants $\mathrm{m}^{-2}$. Regardless of the trial year, pure hoeing always resulted in a significantly higher weed biomass at the time of harvesting than the herbicide applications or the combinations. The weed biomass at the time of harvesting ranged between 0.1 and $54.7 \mathrm{~g} \mathrm{~m}^{-2}$. No significant differences in grain yield between hoeing and herbicide application occurred in all three trial years. According to the results, hoeing is a suitable extension of existing integrated weed control strategies in OSR.

Keywords: canola; herbicides; inter row

\section{Introduction}

Weeds can cause several agronomic problems in oilseed rape (OSR), for example, by competition for nutrients, water, light, and space, and thus lead to a reduction in yield and seed quality [1-3]. Weeds can also cause harvest complications due to their moisture content, and slow the mechanical harvest process. In addition, OSR grains are often soggier after harvest if they had close contact to weed biomass during the threshing process, whereby storability decreases [2,4].

Weed control in OSR is usually performed by herbicides. However, herbicide strategies have to be reconsidered in light of herbicide tolerant crops, a continuing trend to reduced tillage and occurrence of herbicide resistant weeds, and increasing safety concerns about the use of some herbicides [5-12].

A direct way of weed control without herbicides is mechanical control. It could have a more holistic and sustainable effect on weed reduction than herbicide-only measures when implemented in the weed management strategy [8,13-15]. Before herbicides were developed, mechanical weed control was the standard tool for reducing weeds [13]. In organic agriculture, and in low-input agricultural systems, especially in less developed 
countries, mechanical weed control is still the main tool to actively control weeds [14,16]. The main advantage of mechanical weed control is primarily consistent efficacy; weeds cannot develop resistance. In addition, it can be realized with only a modest investment $[16,17]$ On the other hand, mechanical weed control can also have disadvantages, especially in comparison with the use of herbicides. It is not selective, the crop can also be damaged, mostly high effectiveness is achieved only in early stages of development of the weed, its effectiveness depends on weather and soil conditions., and the implementation can be very time-consuming, depending on the method [13,16-18].

OSR plants are very sensitive and are thus not suitable for full-surface harrowing. Therefore, the most promising option is inter-row cultivation, for example, by hoeing. In order to create space for the hoeing tines, the row spacing for OSR can be increased to up to $50 \mathrm{~cm}$ without yield reduction [19]. During hoeing, weeds are destroyed by flat cutting, uprooting, and burying [19-23]. The efficiency of the hoe is higher when weeds are in an early stage of development, the general weed pressure is low, and when its performed under dry soil conditions [19-22]. OSR should have emerged earlier than the weeds and thereby be more resistant to possible damage by hoeing. In addition, crop damage can be prevented by a larger row spacing, the use of camera-guided hoeing systems, and active implement steering especially when hoeing is performed in large scale [19-21,24,25]. In addition, camera-guided hoeing systems make the weed control process more efficient, as higher driving speeds can be applied [18]. Between $65 \%$ and $90 \%$ of the weeds between the rows can be controlled by hoeing $[25,26]$. In maize, hoeing significantly reduced the number of weeds, but did not achieve herbicide efficacy, and yield was lower [21]. For beans (Vigna sinensis L.), mechanical and chemical weed control were found to show no significant differences in weed occurrence and yield [27]. A study with lentils (Lens culinaris) concluded that an integrated approach consisting of increased sowing density, mechanical weed control, and reduced herbicide application rate had the same effect on yield and weed suppression as the standard approach of standard sowing density, full herbicide application and no mechanical weed control [28]. In a study with organically cultivated OSR hoeing significantly reduced the number of weeds [29]. Weed control between the rows may be sufficient to prevent crop depression, as OSR is highly competitive and can effectively shade the soil and other weeds through its branches [19].

The aim of this study is to evaluate hoeing as mechanical inter-row weed control compared with a common herbicide strategy with regard to weed appearance, weed biomass, and OSR grain yield. We hypothesize that hoeing has similar efficacy on weed control such as herbicides; mechanical and chemical weed control result in similar OSR grain yield.

\section{Materials and Methods}

A three-year field trial with oilseed rape (OSR, Brassica napus L.) was conducted in the years 2014/2015, 2015/2016, and 2016/2017 at the experimental station 'Ihinger Hof' of the University of Hohenheim, Stuttgart, South-West Germany (Luvisol, soil type: loam). The average annual precipitation of the location is $690 \mathrm{~mm}$ and the average annual temperature is $7.9^{\circ} \mathrm{C}$. The monthly average temperature and the monthly precipitation for the entire trial period are provided in Figure 1. 


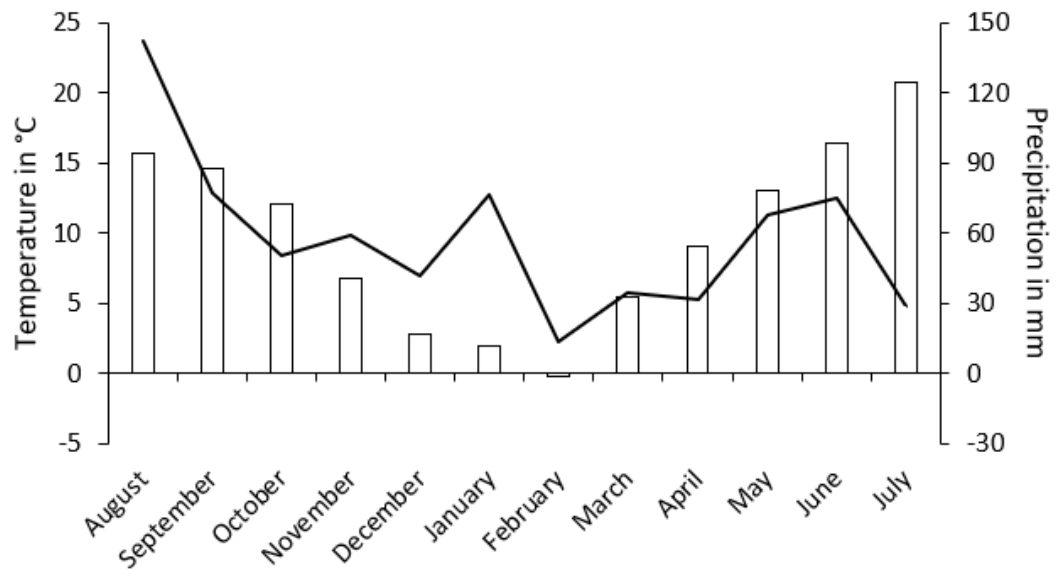

$\square$ Average temperature in ${ }^{\circ} \mathrm{C} \quad \longrightarrow$ Total monthly precipitation in $\mathrm{mm}$

(A)

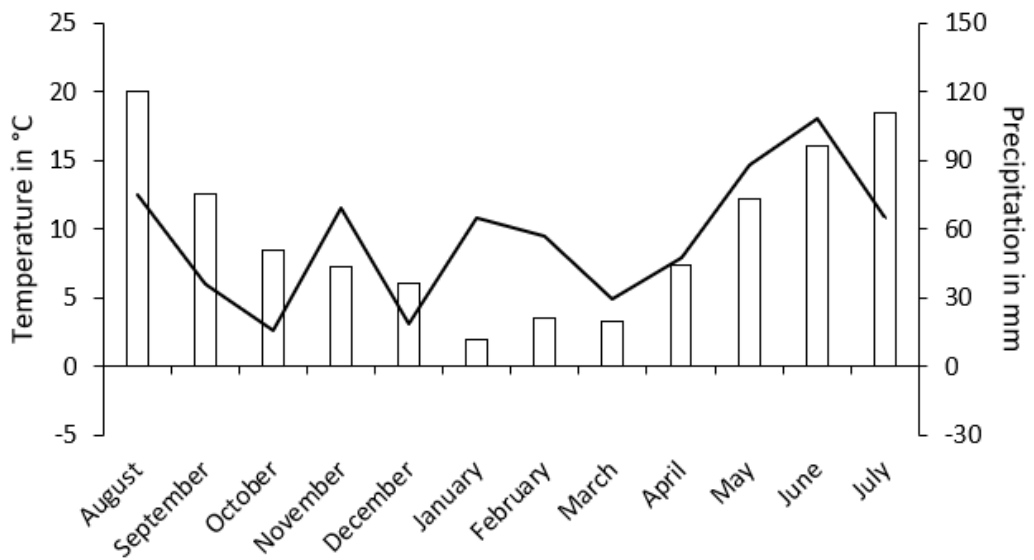

$\square$ Average temperature in ${ }^{\circ} \mathrm{C} \quad-$ Total monthly precipitation in $\mathrm{mm}$

(B)

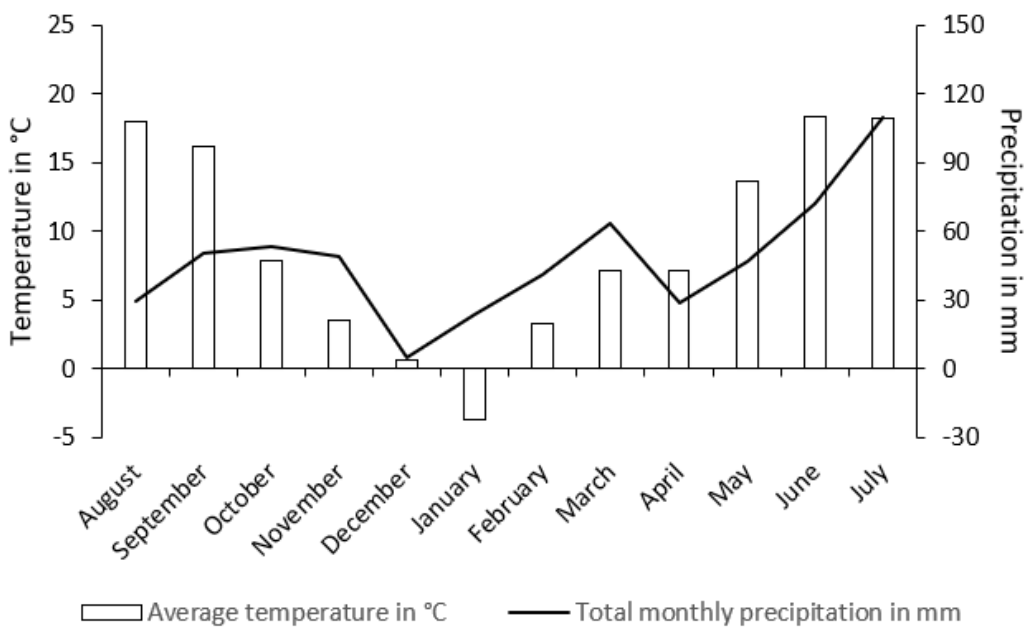

(C)

Figure 1. Monthly average temperature and total monthly precipitation for the trial years 2014/2015 (A), 2015/2016 (B), 2016/2017 (C); experimental station Ihinger Hof, Germany.

The trial was set up with two factors in a split-plot design with four replicates. The main factor (factor 1) was weed control, consisting of the treatments hoeing combined with 
usage of a common herbicide strategy $(\mathrm{HO}+\mathrm{HE})$, hoeing without herbicide application $(\mathrm{HO})$ and the usage of a common herbicide strategy without hoeing (HE). In the treatments $\mathrm{HO}$ and $\mathrm{HO}+\mathrm{HE}$ hoeing was performed twice per trial year. The first hoeing in autumn was performed as soon as the OSR had reached the 6-leaf growth stage and soil and weather conditions were suitable for the operation. The second hoeing was performed in spring as soon as the soil was trafficable. To enable hoeing the row spacing was $24 \mathrm{~cm}$ in all treatments. The tines of the hoe had a width of $16 \mathrm{~cm}$ and a cutting distance of $24 \mathrm{~cm}$. Working depth was $4 \mathrm{~cm}$. Factor 2 was the variety of winter OSR in two levels (varieties), variety 1 and variety 2 . The sowing density was 45 seeds $\mathrm{m}^{-2}$. The experiment was blocked by replicate and weed control. The experiment was conducted on a different field of the experimental station in each growing season. The preceding crop was winter barley in each case. Before sowing, conventional tillage was carried out with the plough and subsequent cultivation with the rotary harrow.

The sowing, harvest, and hoeing dates of all trial years are displayed in Table 1. During the growing season the weed plant density (WPD) was counted. Data were collected shortly before mechanical weed control and three weeks after weed control to describe the efficacy of hoeing (Table 1). WPD was counted ten times per plot with a $0.1 \mathrm{~m}^{2}$ frame and calculated to plants $\mathrm{m}^{-2}$.

Table 1. Sowing, hoeing, weed count, and harvest dates of a three-year weed control experiment in oilseed rape at the research station Ihinger Hof, SW Germany.

\begin{tabular}{cccc}
\hline Process & $\mathbf{2 0 1 4 / 2 0 1 5}$ & $\mathbf{2 0 1 5 / 2 0 1 6}$ & $\mathbf{2 0 1 6 / 2 0 1 7}$ \\
\hline Sowing & 3 September & 27 August & 25 August \\
Weed count & 24 October & 30 September & 30 November \\
Hoeing autumn & 28 October & 1 October & 2 December \\
Weed count & 17 November & 19 October & 20 December \\
Weed count & 16 March & 22 March & 20 March \\
Hoeing spring & 18 March & 24 March & March \\
Weed count & 10 April & 18 April & 12 April \\
Harvest & 28 July & 30 July & 29 July \\
\hline
\end{tabular}

The plant protection program, consisting of insecticides, herbicides and fungicides, and the fertilizer strategy of the experiment is provided in Table 2.

The above-ground weed biomass (WBM) was sampled at four spots of $0.5 \mathrm{~m}^{2}$ each in the plot within one week before harvest, dried for $24 \mathrm{~h}$ at $95^{\circ} \mathrm{C}$, and then weighed. The OSR harvest was carried out with a plot combine. A strip of $2 \mathrm{~m} \times 6 \mathrm{~m}$ was harvested in the middle of each plot. Based on the amount harvested per strip, the grain yield was calculated in $\mathrm{t}$ dry matter per ha. To calculate dry matter, grain samples from each plot were dried at $95^{\circ} \mathrm{C}$ for $24 \mathrm{~h}$, and then weighed.

\section{Statistical Analysis}

The statistical analysis as Student's t-test was performed using the Glimmix and Mixed procedures of the SAS 9.3 software. Data of weed biomass and grain yield were statistically analyzed by using the procedure mixed. Data of weed plant density were analyzed by using the procedure Glimmix. In the statistical model, the following factors were defined as fixed effects: weed control; variety; interactions of weed control, and variety. The following factors were defined as random effects: replicate; interactions of replicate, and weed control. Transformations were partly necessary to reach normal distribution of data. In the statistical analysis of weed plant density, the data were logarithmically transformed. In terms of weed biomass, the data from 2014/2015 and 2016/2017 were square-root transformed, the year two was logarithmically transformed. A transformation was not required for the grain yield data. For presentation purposes, the following figures show only back-transformed data. 
Table 2. Application date of insecticide, fungicide, herbicide, and fertilizer treatments, including agent, trade name and manufacturer, during a three-year weed control experiment in oilseed rape.

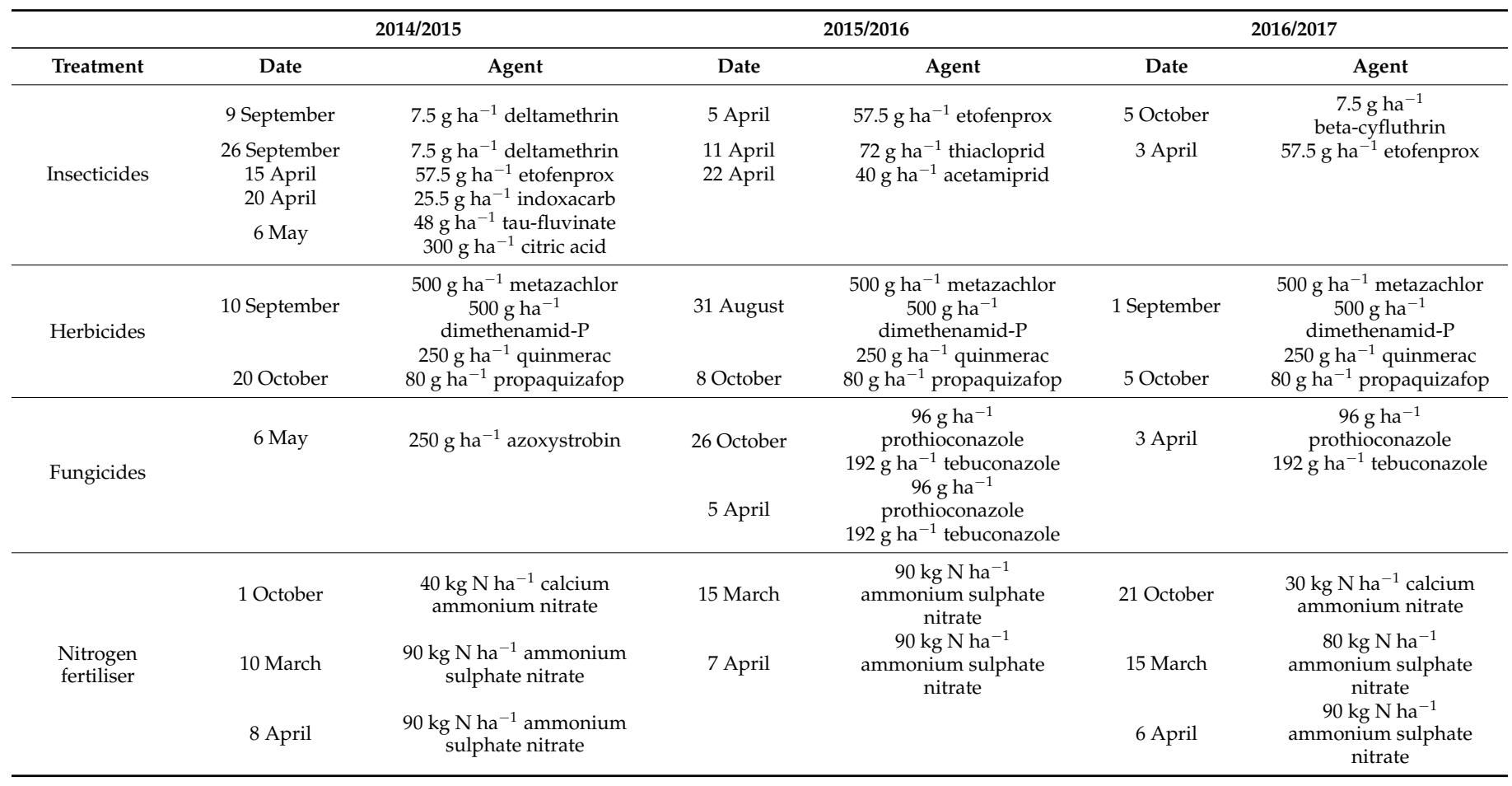

\section{Results}

\subsection{Weeds}

The following weeds occurred during the trial period: Thlaspi arvense L., Stellaria media L., Hordeum vulgare L., Sonchus arvensis L., Veronica agrestis L., Lamium purpureum L., Galium aparine L., Capsella bursa-pastoris L., Geranium rotundifolium L., Matricaria chamomilla L., Cirsium arvense L., Falopia convolvulus L., Fumaria officinalis L., and Alopecurus myosuroides Huds. The dominant weeds in the trial year 2014/2015 were Thlaspi arvense L. and Stellaria media L. In the trial years 2015/2016 and 2016/2017 the dominant weeds were Fumaria officinalis L., Thlaspi arvense L., and Stellaria media L.

The WPD in trial year 2015/2016 decreased in all treatments during the season, as mean over both OSR varieties. The WPD ranged from 2.2 plants $\mathrm{m}^{-2}(\mathrm{HO}+\mathrm{HE} /$ counting 4 ; Figure 2) to 34.4 (HO/counting 1). Across all countings, $\mathrm{HO}$ resulted in the highest number of weeds.

The level of weed infestation in trial year 2015/2016 was lower compared to 2014/2015 (Figure 2), and ranged between 0.6 plants $\mathrm{m}^{-2}(\mathrm{HO}+\mathrm{HE} /$ counting 3$)$ and 7.5 plants $\mathrm{m}^{-2}$ ( $\mathrm{HO} /$ counting 4$)$. From counting 1 to 3 , weed number stayed within a narrow range from $0.6(\mathrm{HO}+\mathrm{HE} /$ counting 3$)$ to 4.5 plants $\mathrm{m}^{-2}(\mathrm{HO} /$ counting 1$)$ At counting 4 , weed numbers in $\mathrm{HO}\left(7.5\right.$ plants $\left.\mathrm{m}^{-2}\right)$ were significantly higher than in $\mathrm{HE}\left(0.7\right.$ plants $\left.\mathrm{m}^{-2}\right)$ and $\mathrm{HO}+\mathrm{HE}$ (1.0 plants $\left.\mathrm{m}^{-2}\right)$.

The highest number of weeds of all trial years was observed in trial year 2016/2017 (Figure 2) and ranged between 0.5 plants $\mathrm{m}^{-2}(\mathrm{HO}+\mathrm{HE} /$ counting 3$)$ and $57.8(\mathrm{HO} /$ counting 1$)$. There were significantly more weeds in all countings in treatment $\mathrm{HO}$ compared to $\mathrm{HO}+\mathrm{HE}$ and $\mathrm{HE}$. Weed numbers in $\mathrm{HO}+\mathrm{HE}$ and $\mathrm{HE}$ were quite similar, except in counting 4, where significantly more weeds were observed in HE. 

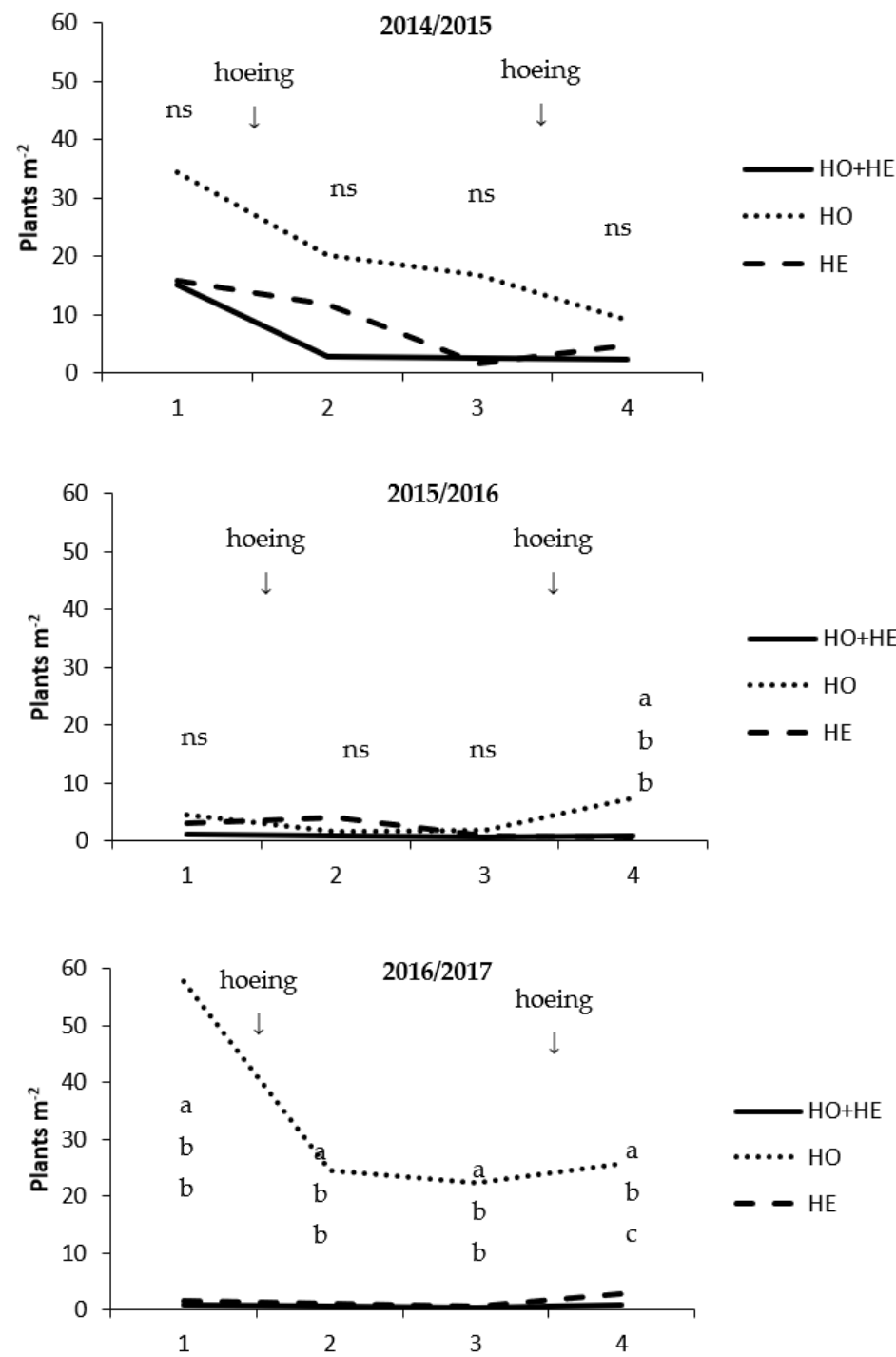

Figure 2. Weed plant density in number of weed plants $\mathrm{m}^{-2}$ in winter oilseed rape (mean of two varieties) before (1) and after (2) hoeing in autumn, and before (3) and after (4) hoeing in spring as effect of the weed control strategies: hoeing + herbicide application $(\mathrm{HO}+\mathrm{HE})$; hoeing without herbicide application (HO); herbicide application without hoeing (HE); herbicides as depicted in Table 2; values within the same time of survey with different letters within are significantly different; non-significant differences are indicated by the abbreviation ' $\mathrm{ns}$ '. (Student's $t$-test on transformed values; $\alpha=0.05)$; experimental station Ihinger Hof, Germany.

The fixed effects of the statistical analyses of WPD for the four annual weed counts in the three trial years are shown in Table 3. If significant effects occurred, then only in the weed control factor. The factor variety and interactions from the factors variety and weed control had no significant influence.

WBM was highest in HO in all years, and ranged from 0.1 (HE, 2015/2016) to $107.6 \mathrm{~g} \mathrm{~m}^{-2}$ (HO, 2014/2015; Figure 3). Independent of trial year WBM in HO + HE and $\mathrm{HE}$ was by 76 to $99 \%$ lower compared to HO. The years differed in weed with WDM of HO as reference: 2015/2016 (HO: $18.1 \mathrm{~g} \mathrm{~m}^{-2}$ ); 2016/2017 (HO: $54.7 \mathrm{~g} \mathrm{~m}^{-2}$ ); and 2014/2015 (HO: $107.6 \mathrm{~g} \mathrm{~m}^{-2}$ ). 
Table 3. Degrees of freedom (DF), F value and probability level ( $\operatorname{Pr}>\mathrm{F})$ of the fixed effects weed control $(\mathrm{WC})$, variety $(\mathrm{V})$, and their interactions $(\mathrm{WC} \times \mathrm{V})$ of the statistical analyses of the weed plant density of four annual weed counts in a three-year weed control experiment in oilseed rape at the research station Ihinger Hof, SW Germany.

\begin{tabular}{|c|c|c|c|c|}
\hline & & DF & F Value & $\operatorname{Pr}>F$ \\
\hline \multicolumn{2}{|c|}{ Weed count } & \multicolumn{3}{|c|}{1} \\
\hline \multirow{3}{*}{$2014 / 2015$} & WC & 2 & 0.77 & 0.5050 \\
\hline & V & 1 & 0.02 & 0.8879 \\
\hline & $\mathrm{WC} \times \mathrm{V}$ & 2 & 2.29 & 0.1567 \\
\hline \multirow{3}{*}{$2015 / 2016$} & WC & 2 & 3.07 & 0.1205 \\
\hline & V & 1 & 0.05 & 0.8275 \\
\hline & $\mathrm{WC} \times \mathrm{V}$ & 2 & 0.50 & 0.6229 \\
\hline \multirow{3}{*}{$2016 / 2017$} & WC & 2 & 42.84 & 0.0003 \\
\hline & V & 1 & 0.59 & 0.4631 \\
\hline & $\mathrm{WC} \times \mathrm{V}$ & 2 & 0.67 & 0.5337 \\
\hline \multicolumn{2}{|c|}{ Weed count } & \multicolumn{3}{|c|}{2} \\
\hline \multirow{3}{*}{$2014 / 2015$} & WC & 2 & 2.90 & 0.1316 \\
\hline & V & 1 & 1.68 & 0.2269 \\
\hline & $\mathrm{WC} \times \mathrm{V}$ & 2 & 0.81 & 0.4732 \\
\hline \multirow{3}{*}{$2015 / 2016$} & WC & 2 & 2.94 & 0.1288 \\
\hline & V & 1 & 0.64 & 0.4432 \\
\hline & $\mathrm{WC} \times \mathrm{V}$ & 2 & 3.81 & 0.2634 \\
\hline \multirow{3}{*}{$2016 / 2017$} & WC & 2 & 49.18 & 0.0002 \\
\hline & V & 1 & 0.70 & 0.4237 \\
\hline & $\mathrm{WC} \times \mathrm{V}$ & 2 & 0.53 & 0.6043 \\
\hline \multicolumn{2}{|c|}{ Weed count } & \multicolumn{3}{|c|}{3} \\
\hline \multirow{3}{*}{$2014 / 2015$} & WC & 2 & 3.16 & 0.1155 \\
\hline & V & 1 & 0.39 & 0.5461 \\
\hline & $\mathrm{WC} \times \mathrm{V}$ & 2 & 0.20 & 0.8221 \\
\hline \multirow{3}{*}{$2015 / 2016$} & WC & 2 & 3.03 & 0.1230 \\
\hline & V & 1 & 2.97 & 0.1188 \\
\hline & $\mathrm{WC} \times \mathrm{V}$ & 2 & 0.38 & 0.6919 \\
\hline \multirow{3}{*}{$2016 / 2017$} & WC & 2 & 114.78 & $<0.0001$ \\
\hline & $\mathrm{V}$ & 1 & 1.36 & 0.2730 \\
\hline & $\mathrm{WC} \times \mathrm{V}$ & 2 & 0.36 & 0.7050 \\
\hline \multicolumn{2}{|c|}{ Weed count } & \multicolumn{3}{|c|}{4} \\
\hline \multirow{3}{*}{$2014 / 2015$} & WC & 2 & 1.15 & 0.3783 \\
\hline & $\mathrm{V}$ & 1 & 0.29 & 0.6018 \\
\hline & $\mathrm{WC} \times \mathrm{V}$ & 2 & 0.15 & 0.8668 \\
\hline \multirow{3}{*}{$2015 / 2016$} & WC & 2 & 16.41 & 0.0037 \\
\hline & V & 1 & 18.08 & 0.1521 \\
\hline & $\mathrm{WC} \times \mathrm{V}$ & 2 & 5.47 & 0.4279 \\
\hline \multirow{3}{*}{$2016 / 2017$} & WC & 2 & 23.80 & 0.0014 \\
\hline & V & 1 & 1.24 & 0.2941 \\
\hline & $\mathrm{WC} \times \mathrm{V}$ & 2 & 0.44 & 0.6556 \\
\hline
\end{tabular}




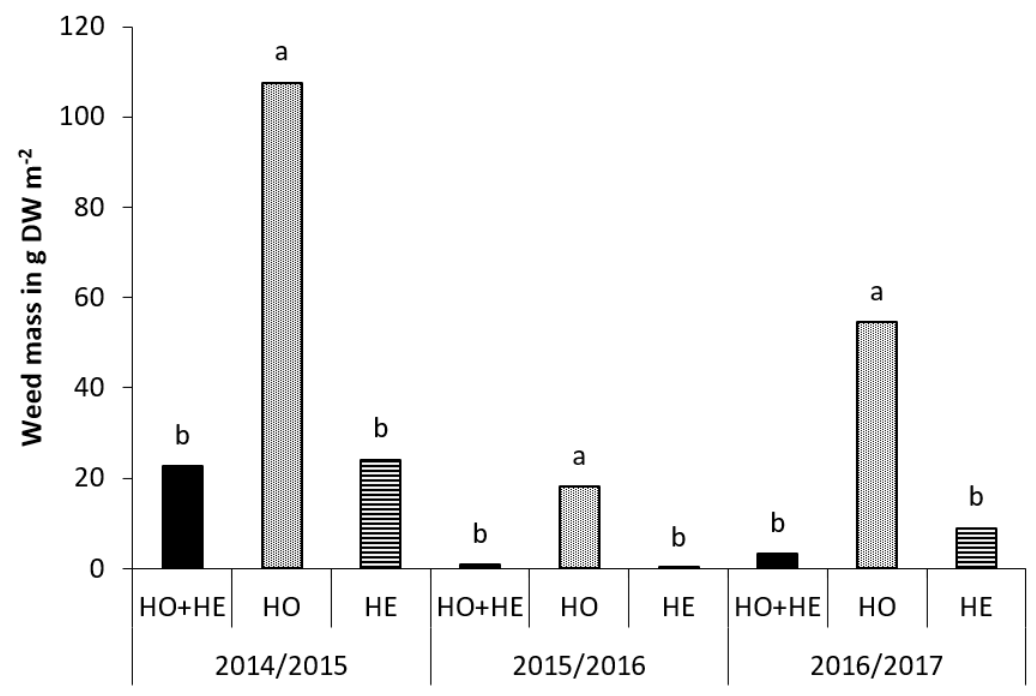

Figure 3. Weed biomass $\left(\mathrm{g} \mathrm{m}^{-2}\right)$ in winter oilseed rape (mean of two varieties) in the trial years 2014/2015, 2015/2016, and 2016/2017 depending on weed control: hoeing + common herbicide strategy $(\mathrm{HO}+\mathrm{HE})$; hoeing without any herbicides $(\mathrm{HO})$; common herbicide strategy without hoeing (HE). Different letters within one trial year indicate significant differences (Student's $t$-test on transformed values; $\alpha=0.05$ ); experimental station Ihinger Hof, Germany.

The fixed effects of the statistical analyses of WPD in the three trial years are shown in Table 4. If significant effects occurred, then only in the weed control factor. The factor variety and interactions from the factors variety and weed control had no significant influence.

Table 4. Degrees of freedom (DF), F value and probability level $(\operatorname{Pr}>\mathrm{F})$ of the fixed effects weed control $(\mathrm{WC})$, variety $(\mathrm{V})$, and their interactions $(\mathrm{WC} \times \mathrm{V})$ of the statistical analyses of the weed biomass in a three-year weed control experiment in oilseed rape at the research station Ihinger Hof, SW Germany.

\begin{tabular}{ccccc}
\hline Trial Year & Effect & DF & F Value & Pr $>$ F \\
\hline \multirow{2}{*}{$2014 / 2015$} & WC & 2 & 6.32 & 0.0333 \\
& V & 1 & 3.32 & 0.1015 \\
& WC $\times$ V & 2 & 0.44 & 0.6601 \\
\hline \multirow{2}{*}{$2015 / 2016$} & WC & 2 & 9.29 & 0.0145 \\
& V & 1 & 5.24 & 0.0578 \\
& WC $\times$ V & 2 & 0.29 & 0.7553 \\
\hline \multirow{2}{*}{$2016 / 2017$} & WC & 2 & 5.61 & 0.0422 \\
& V & 1 & 10.24 & 0.0708 \\
& WC $\times$ V & 2 & 9.45 & 0.1062 \\
\hline
\end{tabular}

\subsection{Oilseed Rape Grain Yield}

The grain yield ranged from 2.9 t DM (HO, 2015/2016) to $3.9 \mathrm{t} \mathrm{DM} \mathrm{ha}^{-1}(\mathrm{HO}+\mathrm{HE}$, 2016/2017; Figure 4). Significant differences between the treatments occurred only in 2016/2017; lowest grain yield however, was always obtained in treatment HO. The significant yield gap between $\mathrm{HO}$ and $\mathrm{HO}+\mathrm{HE}$ in 206/2017 was $0.6 \mathrm{t} \mathrm{ha}^{-1}$. 


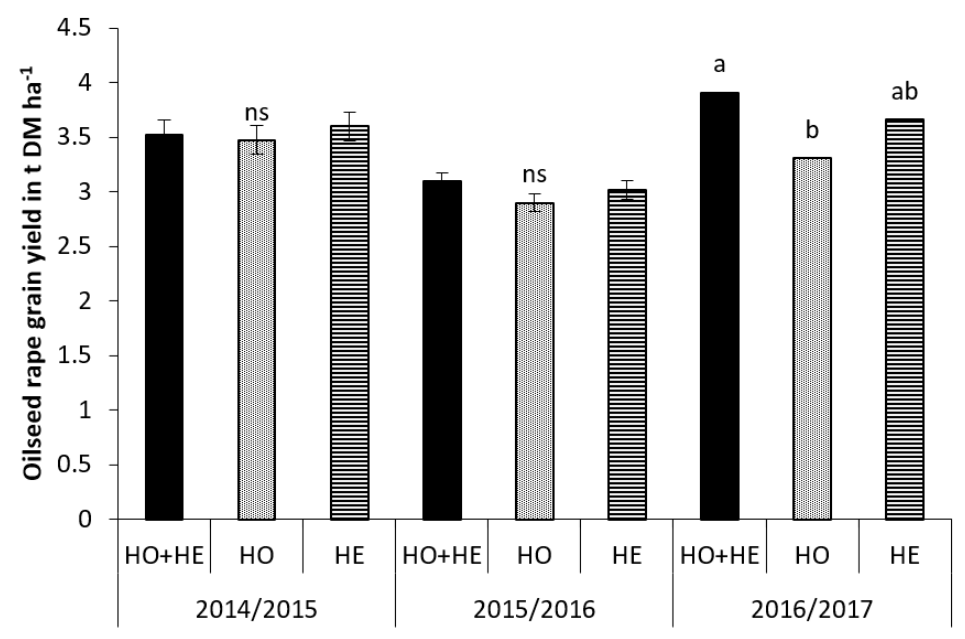

Figure 4. Grain yield of two oilseed rape varieties ( $t$ dry matter (DM) ha ${ }^{-1}$ ) in the trial years 2014/2015, 2015/2016, and 2016/2017 dependent of the weed control strategy: hoeing + common herbicide strategy $(\mathrm{HO}+\mathrm{HE})$; hoeing without any herbicides $(\mathrm{HO})$; common herbicide strategy without hoeing (HE). Different letters within one trial year indicate significant differences; if no significant differences (ns) occurred, the standard error of mean (SE) was displayed as error bar in the figure (Student's $t$-test; $\alpha=0.05$ ); experimental station Ihinger Hof.

The fixed effects of the statistical analyses of the grain yield in the three trial years are shown in Table 5. If significant effects occurred, then only in the weed control factor. The factor variety and interactions from the factors variety and weed control had no significant influence.

Table 5. Degrees of freedom (DF), $\mathrm{F}$ value and probability level $(\mathrm{Pr}>\mathrm{F})$ of the fixed effects weed control $(\mathrm{WC})$, variety $(\mathrm{V})$, and their interactions $(\mathrm{WC} \times \mathrm{V})$ of the statistical analyses of the grain yield in a three-year weed control experiment in oilseed rape at the research station Ihinger Hof, SW Germany.

\begin{tabular}{ccccc}
\hline Trial Year & Effect & DF & F Value & Pr $>$ F \\
\hline \multirow{2}{*}{$2014 / 2015$} & WC & 2 & 0.49 & 0.6332 \\
& V & 1 & 0.48 & 0.5069 \\
& WC $\times$ V & 2 & 0.63 & 0.5536 \\
\hline \multirow{2}{*}{$2015 / 2016$} & WC & 2 & 2.74 & 0.1429 \\
& V & 1 & 0.22 & 0.6528 \\
& WC $\times$ V & 2 & 1.53 & 0.2685 \\
\hline \multirow{2}{*}{$2016 / 2017$} & WC & 2 & 6.93 & 0.0276 \\
& V & 1 & 1.90 & 0.2014 \\
& WC $\times$ V & 2 & 0.06 & 0.9408 \\
\hline
\end{tabular}

\section{Discussion}

The success of hoeing in controlling weeds and promoting high OSR grain yield depends on the general weed pressure, and on the weather conditions, dry soils allow a higher efficiency of the hoeing [23]. The general weed pressure differed over the three trial years. When comparing WPD and WDM (Figures 2 and 3), the general weed pressure in the test years 2014/2015 and 2016/2017 appears to be higher than in the test year $2015 / 2016$. This may be due to soil seed banks of different sizes and species composition on the respective trial fields. In addition, the annual weather conditions can have an influence on the emergence of weeds. In particular, it is noticeable that there were hardly any sunshine hours in the trial year 2015/2016 (Figure 1B), which meant that less light reached the soil and fewer weeds were stimulated to germinate. In addition, September and October of the year were relatively dry and counteracted strong weed emergencies 
(Figure 1). Nevertheless, the higher number of weeds was mostly found in the $\mathrm{HO}$ variant. Even though these differences were only partially significant, a clear tendency can still be seen with higher weed pressures (trial years 2014/2015 and 2016/2017). The differences in efficiency in $\mathrm{HO}$ can be explained by the fact that hoeing does not take place over the entire surface, and therefore parts of the surface cannot be cultivated [26]. With a row spacing of $24 \mathrm{~cm}$ between the OSR plants, only $16 \mathrm{~cm}$ were cultivated by the hoeing coulter per row, while weeds on the remaining $8 \mathrm{~cm}$ could not be controlled. The effect of hoeing on weeds is based on uprooting, flat cutting, and burying [19-23]. It cannot be excluded that cut-off weeds can sprout again or re-grow especially if they are in an advanced growth stage [19-22]. The number of weeds in the $\mathrm{HE}$ and $\mathrm{HO}+\mathrm{HE}$ variants was similar, and in the years 2014/2015 and 2016/2017, was either tending or significantly lower than the number of weeds in the $\mathrm{HO}$ variant. The lower number of weeds in the $\mathrm{HE}$ and $\mathrm{HO}+\mathrm{HE}$ variants, compared to the HO variant, especially in the trial years 2014/2015 and 2016/2017, is due to the fact that weed control by the herbicides took place over the entire area and their efficacy is higher. For better mechanical weed control within the rows by hoeing, specialised hoes can also be equipped with intra-row elements. This could control up to $78 \%$ of the weeds within the rows and could lead to smaller differences between the chemical and mechanical variants of weed control [25]. Surprisingly, the number of weeds in $\mathrm{HO}+\mathrm{HE}$ was less than in HE. As hoeing is an intervention in the soil, it would be likely that the active agent layer formed above the soil by the herbicides would be damaged and that as a result more weeds would emerge. In some cases, however, the opposite was true. Especially in counting 2 in the trial year 2014/2015 and counting 4 in the trial years 2014/2015 and 2016/2017 (Figure 2). In counting 2 of the trial year 2014/2015, the effect of the herbicide had probably not yet fully taken impact due to the weather conditions. Compared to the other two trial years, the months September to November (time between sowing and counting 2) were relatively warm, with high precipitation and hours of sunshine (Figure 1). These vigorous conditions could lead to an increased weed emergence, so that new weeds may have emerged between the counting 1 and counting 2; and the weeds could be more vital, which may cause them to react later to herbicide application. Weeds that did not yet show lethal symptoms and died later in the year may have been counted. As the year progressed, the effectiveness of the soil herbicide probably decreased and new weeds could accumulate in the $\mathrm{HO}$ variant during the fourth counting period [30,31]. This loss of efficacy was compensated by hoeing in the $\mathrm{HO}+\mathrm{HE}$ variant. Such a trend cannot be detected for the 2015/2016 trial year because the general weed pressure was probably too low.

As the number of weeds in the counting 4 at least tended to indicate, the weed mass at harvesting in the $\mathrm{HO}$ variant is significantly higher in all trial years than in the other two variants. The reason for the different weed masses in the three experimental years is the difference in the weight of the individual weed plants, which occur due to different weather conditions and a specific weed composition.

With regard to grain yield, no significant differences were found in all three trial years between the herbicide application method used in conventional agricultural practice in the $\mathrm{HE}$ variant and the hoeing method without the use of herbicides in the $\mathrm{HO}$ variant. The competitive capacity of OSR, based mainly on the formation of branches, seemed to be greater than the effect of weeds on yield $[4,19]$. The combination of hoeing and herbicide use in $\mathrm{HO}+\mathrm{HE}$ resulted in a significantly higher yield in the trial year 2016/2017 than in $\mathrm{HO}$, and can probably be explained by a significantly lower weed amount in combination with a tendency to lower weed mass at harvest.

According to the results, hoeing as a mechanical weed control option can be regarded as an alternative to the herbicide use previously practiced in conventional agriculture. However, if the hoe is used over a large area at higher speeds, care must be taken not to damage the OSR plants, which could also have a negative effect on grain yield [18]. It would be advisable to use camera-guided systems for this purpose and to choose a row spacing between 24 and $50 \mathrm{~cm}$, then the occurrence of damage would be unlikely [18-21]. However, the renunciation of herbicides resulted in an increased number of weeds. It 
can be assumed that weeds that have not been controlled before the threshing stage of the OSR will reach seed maturity, and that weed seeds will accumulate increasingly in the soil seed bank and that the general weed pressure could increase in the following years. The comparison of WPD (Figure 2) shows that the effectiveness of hoeing is lower at higher weed pressure (comparison of the test years 2014/2015 and 2017/2018 with higher weed pressure with the test year 2016/2017 with lower weed pressure). If herbicides are consistently avoided for several years during mechanical weed control by hoeing, it is likely that the effectiveness of hoeing will decline further due to the increasing weed pressure. In order to successfully control weeds without herbicides over several years, holistic approaches are needed in addition to direct mechanical weed control, including long crop rotations, mulching, adapted tillage, optimized sowing operation, and the use of selected intercrops [3,32-36]. However, hoeing is particularly suitable in an environment of social desire for more ecological agriculture, where there are increasing bans or restrictions on the use of herbicides and a lack of approval of new herbicidal active agents as a supplement to chemical crop protection, therefore providing an additional way of controlling weeds that became difficult to control chemically $[18,25,37]$.

\section{Conclusions}

Hoeing is a suitable option for weed control in OSR. Compared to chemical herbicide application, weeds can be controlled less efficiently by hoeing. However, this is not necessarily related to yield losses. This is especially true when highly competitive hybrid oilseed rape varieties are used [38]. Moreover, hoeing can be combined with a chemical weed control strategy, which can be expected to improve the control of resistant weeds.

Author Contributions: Conceptualization, S.S., S.G. and W.C.; methodology, S.S., S.G. and W.C.; software, S.S.; validation, S.S.; formal analysis, S.S.; investigation, S.S.; resources, S.S., S.G. and W.C.; data curation, S.S.; writing-original draft preparation, S.S.; writing-review and editing, S.G. and W.C.; visualization, S.S.; supervision, S.G. and W.C.; project administration, S.G. and W.C.; funding acquisition, S.G. and W.C. All authors have read and agreed to the published version of the manuscript.

Funding: This research was funded by Dow AgroSciences GmbH (Germany), grant number 340571.

Institutional Review Board Statement: Not applicable.

Informed Consent Statement: Not applicable.

Data Availability Statement: The data presented in this study are available upon request from the corresponding author.

Conflicts of Interest: The authors declare no conflict of interest.

\section{References}

1. Salisbury, P.A.; Potter, T.D.; Gurung, A.M.; Mailer, R.J.; Williams, W.M. Potential impact of weedy Brassicaceae species on oil and meal quality of oilseed rape (canola) in Australia. Weed Res. 2018, 58, 200-209. [CrossRef]

2. Llewellyn, R.; Ronning, D.; Clarke, M.; Mayfield, A.; Walker, S.; Ouzman, J. Impact of Weeds on Australian Grain Production: The Cost of Weeds to Australian Grain Growers and the Adoption of Weed Management and Tillage Practices; Report for Grains Research and Development Corporation, CSIRO: Canberra, Australia, March 2016.

3. Sharma, G.; Shrestha, S.; Kunwar, S.; Tseng, T.M. Crop diversification for improved weed management: A review. Agriculture 2021, 11, 461. [CrossRef]

4. Beckie, H.J.; Johnson, E.N.; Blackshaw, R.E.; Gan, Y. Weed Suppression by Canola and Mustard Cultivars. Weed Technol. 2008, 22, 182-185. [CrossRef]

5. Statistisches Bundesamt. Land- und Forstwirtschaft, Fischerei. Bodenbearbeitung, Bewässerung, Landschaftselemente, Erhebung über landwirtschaftliche Produktionsmethoden; Statistisches Bundesamt: Wiesbaden, Germany, 2011. Available online: https://www.destatis. de/DE/Themen/Branchen-Unternehmen/Landwirtschaft-Forstwirtschaft-Fischerei/Produktionsmethoden/Publikationen/ Downloads-Produktionsmethoden/bodenbearbeitung-bewaesserung-2032805109004.pdf?_blob=publicationFile (accessed on 21 November 2021). 
6. Statistisches Bundesamt. Land- und Forstwirtschaft, Fischerei. Bodenbearbeitung, Erosionsschutz, Fruchtwechsel/Agrarstrukturerhebung; Statistisches Bundesamt: Wiesbaden, Germany, 2017. Available online: https://www.destatis.de/DE/Themen/BranchenUnternehmen/Landwirtschaft-Forstwirtschaft-Fischerei/Produktionsmethoden/Publikationen/Downloads-Produktionsmethoden/ bodenbearbeitung-erosionsschutz-fruchtwechsel-5411209169004.pdf?_blob=publicationFile (accessed on 21 November 2021).

7. Beckie, H.J. Herbicide-Resistant Weeds: Management Tactics and Practices. Weed Technol. 2006, 20, 793-814. [CrossRef]

8. Asaduzzaman, M.; Pratley, J.E.; Luckett, D.; Lemerle, D.; Wu, H. Weed management in canola (Brassica napus L): A review of current constraints and future strategies for Australia. Arch. Agron. Soil Sci. 2020, 66, 427-444. [CrossRef]

9. Milesi, M.M.; Lorenz, V.; Durando, M.; Rossetti, M.F.; Varayoud, J. Glyphosate Herbicide: Reproductive Outcomes and Multigenerational Effects. Front. Endocrinol. 2021, 12, 672532. [CrossRef] [PubMed]

10. Ghanizadeh, H.; Harrington, K.C. Herbicide resistant weeds in New Zealand: State of knowledge. N. Z. J. Agric. Res. 2021, 64, 471-482. [CrossRef]

11. Rao, A.N.; Singh, R.G.; Mahajan, G.; Wani, S.P. Weed research issues, challenges, and opportunities in India. Crop Prot. 2020, 134, 104451. [CrossRef]

12. Krähmer, H.; Andreasen, C.; Economou-Antonaka, G.; Holec, J.; Kalivas, D.; Kolářová, M.; Novák, R.; Panozzo, S.; Pinke, G.; Salonen, J.; et al. Weed surveys and weed mapping in Europe: State of the art and future tasks. Crop Prot. 2020, 129, 105010. [CrossRef]

13. Parish, S. A Review of Non-Chemical Weed Control Techniques. Biol. Agric. Hortic. 1990, 7, 117-137. [CrossRef]

14. Pannacci, E.; Lattanzi, B.; Tei, F. Non-chemical weed management strategies in minor crops: A review. Crop Prot. 2017, 96, 44-58. [CrossRef]

15. Blackshaw, R.E.; Beckie, H.J.; Molnar, L.J.; Entz, T.; Moyer, J.R.; Blackshaw, R.E.; Beckie, H.J.; Moyer, J.R. Combining agronomic practices and herbicides improves weed management in wheat-canola rotations within zero-tillage production systems. Weed Sci. 2005, 53, 528-535. [CrossRef]

16. Wei, D.; Liping, C.; Zhijun, M.; Guangwei, W.; Ruirui, Z. Review of non-chemical weed management for green agriculture. Int. J. Agric. Biol. Eng. 2010, 3, 52-61.

17. Green, J.M.; Owen, M.D.K. Herbicide-Resistant Crops: Utilities and Limitations for Herbicide-Resistant Weed Management. J. Agric. Food Chem. 2011, 59, 5819-5829. [CrossRef]

18. Kunz, C.; Weber, J.F.; Gerhards, R. Benefits of precision farming technologies for mechanical weed control in soybean and sugar beet-Comparison of precision hoeing with conventional mechanical weed control. Agronomy 2015, 5, 130-142. [CrossRef]

19. Melander, B.; Munier-jolain, N.; Wirth, J.; Schwarz, J.; van der Weide, R.; Bonin, L.; Jensen, P.K.; Kudsk, P. European Perspectives on the Adoption of Nonchemical Weed Management in Reduced-Tillage Systems for Arable Crops. Weed Technol. 2013, 27, 231-240. [CrossRef]

20. Bond, W.; Grundy, A.C. Non-chemical weed management in organic farming systems. Weed Res. 2001, 41, 383-405. [CrossRef]

21. Fogliatto, S.; Milan, M.; De Palo, F.; Ferrero, A.; Vidotto, F. Effectiveness of mechanical weed control on Italian flint varieties of maize. Renew. Agric. Food Syst. 2017, 34, 447-459. [CrossRef]

22. Pullen, D.W.M.; Cowell, P.A. An Evaluation of the Performance of Mechanical Weeding Mechanisms for use in High Speed Inter-Row Weeding of Arable Crops. J. Agric. Eng. Res. 1997, 67, 27-34. [CrossRef]

23. Rasmussen, I.A. The effect of sowing date, stale seedbed, row width and mechanical weed control on weeds and yields of organic winter wheat. Weed Res. 2004, 44, 12-20. [CrossRef]

24. Andersen, G.L.; Kuennen, T. CULTI CAM HD-Efficient weed control in row crops using active implement steering and stereo camera. In Land Technik AgEng 2019; VDI Verlag: Düsseldorf, Germany, 2019; pp. 455-461.

25. Kunz, C.; Weber, J.F.; Peteinatos, G.G.; Sökefeld, M.; Gerhards, R. Camera steered mechanical weed control in sugar beet, maize and soybean. Precis. Agric. 2018, 19, 708-720. [CrossRef]

26. Kurstjens, D.A.G. Precise tillage systems for enhanced non-chemical weed management. Soil Tillage Res. 2007, 97, 293-305. [CrossRef]

27. Razaz, M.; Fathi, G.; Enayatgholizadeh, M.R. Effect of chemical, mechanical and Integrated weeds control, on yield and yield component bean (Vigna sinensis L.). Adv. Environ. Biol. 2014, 8, 159-162.

28. Redlick, C.; Syrovy, L.D.; Duddu, H.S.N.; Benaragama, D.; Johnson, E.N.; Willenborg, C.J.; Shirtliffe, S.J. Developing an Integrated Weed Management System for Herbicide-Resistant Weeds Using Lentil (Lens culinaris) as a Model Crop. Weed Sci. 2017, 65, 778-786. [CrossRef]

29. Velička, R.; Marcinkevičienè, A.; Pupalienė, R.; Butkevičienė, L.M.; Kosteckas, R.; Čekanauskas, S.; Kriaučiūnienè, Z. Winter oilseed rape and weed competition in organic farming using non-chemical weed control. Zemdirb.-Agric. 2016, 103, 11-20. [CrossRef]

30. Jursík, M.; Kočárek, M.; Suchanová, M.; Kolářová, M.; Šuk, J. Effect of irrigation and adjuvant on residual activity of pendimethalin and metazachlor in kohlrabi and soil. Plant Soil Environ. 2019, 65, 387-394. [CrossRef]

31. Kočárek, M.; Kodešová, R.; Sharipov, U.; Jursík, M. Effect of adjuvant on pendimethalin and dimethenamid-P behaviour in soil. J. Hazard. Mater. 2018, 354, 266-274. [CrossRef] [PubMed]

32. Gummert, A.; Ladewig, E.; Märländer, B. Guidelines for integrated pest management in sugar beet cultivation-Weed control. J. Für Kult. 2012, 64, 105-111. 
33. Birthisel, S.K.; Clements, R.S.; Gallandt, E.R. Review: How will climate change impact the 'many little hammers' of ecological weed management? Weed Res. 2021, 61, 327-341. [CrossRef]

34. Maqsood, Q.; Abbas, R.N.; Iqbal, M.A.; Serap, K.A.; Iqbal, A.; Sabagh, A. El Overviewing of weed management practices to reduce weed seed bank and to increase maize yield. Planta Daninha 2020, 38, 1-10. [CrossRef]

35. Weisberger, D.; Nichols, V.; Liebman, M. Does diversifying crop rotations suppress weeds? A meta-analysis. PLoS ONE 2019, 14, e0219847. [CrossRef] [PubMed]

36. Gruber, S.; Claupein, W. Effect of soil tillage intensity on seedbank dynamics of oilseed rape compared with plastic pellets as reference material. J. Plant Dis. Prot. 2006, 20, 273-280.

37. Duke, S.O. Why have no new herbicide modes of action appeared in recent years? Pest Manag. Sci. 2012, 68, 505-512. [CrossRef] [PubMed]

38. Lemerle, D.; Luckett, D.J.; Wu, H.; Widderick, M.J. Agronomic interventions for weed management in canola (Brassica napus L.)—A review. Crop Prot. 2017, 95, 69-73. [CrossRef] 